\title{
Circular economy-based reverse logistics: dynamic interplay between sustainable resource commitment and financial performance
}

\author{
Yudi Fernando \\ Department of Business Engineering, Faculty of Industrial Management, \\ Universiti Malaysia Pahang, Gambang, Malaysia and \\ Department of Management, BINUS Online Learning, Bina Nusantara University, \\ Jakarta Barat, Indonesia \\ Muhammad Shabir Shaharudin \\ School of Management, Universiti Sains Malaysia, Penang, Malaysia, and \\ Ahmed Zainul Abideen \\ Department of Business Engineering, Faculty of Industrial Management, \\ Universiti Malaysia Pahang, Gambang, Malaysia
}

\begin{abstract}
Purpose - The study aims to propose a circular economy-based reverse logistics (CERL) that emphasises the mediation effect of reverse logistics (RL) on sustainable resource commitment and financial performance.

Design/methodology/approach - The structural equation modelling (SEM) approach has been applied to analyse the data acquired through the survey method that included 113 vendors of automotive supplies of the 1st and 2nd levels.

Findings - The results confirm that CERL acts as an essential intervening entity between resources and financial performance. The findings of the study have provided research and development (R\&D) opportunities for the industries to find alternative revenue streams and generate profit from resource investment whilst upholding environmental standards through reverse logistic practices.

Practical implications - Reverse logistic practices are the key components of a circular business model and a sustainable supply chain. The manufacturing companies need to explore critical enablers that can contribute to business productivity and financial growth.

Originality/value - The study has validated a CERL model that portrays the circular economy's resilient relationship with RL practices.
\end{abstract}

Keywords Circular economy, Reverse logistics, Resource commitment, Natural-resource-based view,

Automotive, Importance-performance map analysis

Paper type Research paper

(C) Yudi Fernando, Muhammad Shabir Shaharudin and Ahmed Zainul Abideen. Published in European Journal of Management and Business Economics. Published by Emerald Publishing Limited. This article is published under the Creative Commons Attribution (CC BY 4.0) licence. Anyone may reproduce, distribute, translate and create derivative works of this article (for both commercial and noncommercial purposes), subject to full attribution to the original publication and authors. The full terms of this licence may be seen at http://creativecommons.org/licences/by/4.0/legalcode

The authors convey their appreciation to the Division of Research and Innovation, Universiti Malaysia Pahang for funding this study (PGRS190366; PGRS190365 and PGRS190364).

CERL-product return and recovery

Received 30 August 2020 Revised 21 February 2021 5 July 2021

8 September 2021 19 October 2021

Accepted 28 December 2021 
EJMBE 32,1

92

\section{Introduction}

The automotive industry is one of the leading contributors to industrial waste, affecting environmental and financial efficiency (Fernando et al., 2018). The rising demand for automotive products has led to the rapid accumulation of vehicle waste and issues with recycling that eventually created environmental violations (Saraiva et al., 2020). Hence, RL, a sustainable business practice, is needed to assist a company in enhancing material utilisation and reducing cost (Chan et al., 2020). Further, it helps establish practices with lowerenvironmental impact (CRR, 2015). The environmental performance can be improved by reducing environmental degradation and improving operational performance by eliminating surplus raw materials and scraps for recycling (Fernando et al., 2019).

$\mathrm{RL}$ is the part of firms' competency to effectively utilise the resources to handle product returns (Autry et al., 2001). Although RL is not a new concept, there is a need to create a collaborative mechanism to accommodate a circular economy based on RL activities. The firms need to have sufficient capacity to respond to the demand for returnable products and avoid waste and pollution generation (de Campos et al., 2020).

In the automotive sector, RL offers companies an option to improve financial performance by receiving new market segments revenue such as retrofitting and remanufacturing (Chan et al., 2020). Therefore, the favourable constructs of RL and the resource allotment in achieving better performance are given lesser attention. Moreover, previous studies have shown that companies are not fully motivated to follow RL programs, since they demanded additional investment and commitment (Abbas and Farooquie, 2020). After re-fabrication, the market growth contributed $10 \%$ to the overall automotive sector with less contribution from the Malaysian-based automotive industry (US ITC, 2012). Furthermore, reverse supply chain networks are also challenging to manage because of the volatile return rate (Tosarkani et al., 2020). In-depth research is now underway in companies to visualise how RL affects financial performance indirectly (Govindan and Soleimani, 2017).

In terms of profitability, the current economic situation, the pandemic and global competition have struck the non-resilient automotive companies (Pirttilä et al., 2020). Declining sales, increased competition and manufacturing costs directly pressure the industry (Sanni et al., 2020). The challenges can be managed through efficient inventory with integration of the forward logistics (Fernando et al., 2020).

As described in the Sustainable Development Policy of the EU, encouraging sustainable consumption and production is the best option for continuously improving well-being (Jonkute and Staniškis, 2016). However, the automotive industry contributes to greenhouse gas (GHG) emissions and cannot cope with automotive waste (Passarini et al., 2012). Globally, the number of new cars tends to grow annually. Because of its complexity and increasing quantity, the waste produced by end-of-life vehicles (ELVs) is another issue. European ELVs rose by 40\% and exceeded 14 million tonnes from 2010 to 2015 (Passarini et al., 2012).

Most logistic activities are from producers to customers and significantly less attention has been paid to product return and recall (Hofmann and Visagie, 2020). Hence, businesses need to merge their potential logistics process with RL protocol for better revenue prospects (Fernando et al., 2017). However, there is little guidance on how they can attain sustainability and enhance financial performance via RL. Although the literature has widely discussed resource commitment and RL, only a very few empirical studies connect this success to financial performance (Niţă and Ştefea, 2014). The indirect path is not well covered in the literature. Scanty evidence is present to justify that sustainable resource commitment plays a critical role to leverage financial performance. Besides, RL is not often covered as a core competence in automotive businesses. New business models demand more green-oriented production activities that comply with recycling and restructuring architecture. Material reusability, energy quality and recyclability need to be carefully managed. It will assist the 
decision-makers, can keep track of them and ensure that they meet operational specifications (Giampieri et al., 2020).

However, ignoring the RL outcomes of today's supply chain frameworks is inconsistent with previous findings. Kirchoff et al. (2018) argued that RL implementation rubrics and procedures are still unclear. It calls for scholars to further strengthen the theory of circularbased supply chain management, particularly RL as the drivers and the existing supply chain framework (Julianelli et al., 2020). However, the development of a supply chain framework that meets the requirements of today's manufacturing industry needs to have a mediation model that helps to clarify its performance between companies' sustainable resource allocation and RL (Kirchoff et al., 2018).

Automotive sectors strictly require a sustainable circular chain of a commendable business value that can withstand customer refusals, recall, transformation and safe disposal. RL helps directly to develop, enable and improve a circular supply chain model based on eco-innovation policies (Geissdoerfer et al., 2018). Moreover, due to the growing concern on environmental sustainability and cost saving, manufacturing companies have started to produce new products through circular business models (Prieto-Sandoval et al., 2018). The idea of RL has driven proper solid management systems and set up a transitional platform driven towards the circular economy activity (Guarnieri et al., 2020). Batista et al. (2018) postulated that the circularity concept had given potential returns to companies and society.

Furthermore, RL has been technically associated with the circular economy and sustainability (Merli et al., 2018). Despite having a similar concept, the circular economy and RL are discussed separately. It was neglected how the circular economy works well, mimicking the concepts of RL.

This paper aims to examine the emerging concept of CERL and evaluate it as the mediating effect of sustainable resource commitment and financial performance through the mediation of RL practices. This study provides empirical data on CERL practices that lack evidence from the literature, particularly in developing countries such as Malaysia. Although previous literature on RL is precise, CERL is still in the development stage and financial interventions and related practical implications are still not explored. This study thus provides empirical evidence of the CERL model, which predicts the impact of sustainable resource commitment on financial performance.

In practical terms, this paper will help an automotive company to wisely utilise sustainable resources and invest in suitable green technology. In addition, companies can use this study to further develop and improve CERL for business sustainability. At first, this paper discusses the past studies that are related to the main variables, the theoretical model and the hypotheses. Then, the method employed in this study is presented, followed by findings, discussion-based conclusions and importance performance map analysis (IPMA). Last is the conclusion of this study, including limitations and directions for future research.

\section{Theoretical framework}

Companies must comprehend how environmental management can help them attain financial success. Companies have long recognised the need to effectively manage their resources to gain a competitive advantage and improve performance. According to Barney (1991), the resource-based view theory (RBV) has underpinning theory to predict enablers of adequate resources management to achieve performance. The RBV theory sheds light on the importance of resource commitment and how organisations that manage their resources can be crafted as distinctive, having a competitive advantage through improved performance.

It is challenging to retain competitive advantage or consistently achieve performance when environmental and technological advancements are the centre of attention in the current business environment. Thus, Davcik and Sharma (2016) suggested that companies' decisions on resource management start with how many resources 
EJMBE 32,1 companies are willing to commit for their product or supply chain process. As a result, resource commitment severely impacts the overall implementation of the product revenues (Maiti et al., 2020).

Environmental practice has an impact on business performance and attracts stakeholders' attention. Moreover, previous scholars had previously criticised the RBV theory for not considering the external environment of the companies. Hart (1995) established the natural RBV (NRBV) theory as an effective alternative and a guiding pathway for competitive advantage by closely considering eco-friendly and sustainability factors. This argument was exacerbated further by stakeholder pressure on firms to take a proactive approach to environmental protection. The adoption of NRBV theory is also motivated by the concept of social responsibility (Lopez-Becerra and Alcon, 2021).

Thus, it is no longer acceptable for companies to rely on resource commitment practice alone to achieve performance and competitive advantage. RBV theory's limitation cannot provide better guidance for companies to adapt to the dynamic and complex stakeholders' environmental-based requirements. Michalisin and Stinchfield (2010) suggested the limitation of RBV can be solved using NRBV, where it explains the heterogeneity of constraints imposed by natural resources, which considers environmental practices as primary drivers to achieve performance. Hart (1995) recommends three strategies for companies to achieve performance. The first strategy is the pollution prevention strategy where it helps companies reduce operational cost by reducing emissions and improve other operations. The second strategy is product stewardship where it helps companies gain a competitive advantage financially by reducing life-cycle cost through supply chain integration. The third strategy is sustainable development to position the organisation as one of the industry leaders by minimising environmental hazards through a shared vision with other players in the sector.

Although NRBV theory explains how organisations can retain competitive advantage and performance by implementing environmental management, the knowledge extension is onesided. It fails to differentiate itself from RBV theory and the idea of resource commitment explained by NRBV theory. The limitations can be presented through the work of Hart (1995), where the three strategies had been specifically mentioned. Thus, scholars have been investigating the performance of companies through the lenses of these three strategies. Whilst pollution prevention and product stewardship are more specific, the sustainable development strategy is used by scholars to include other critical environmental practices that are specific to the industry or context of research, such as supply chain and operations (McDougall et al., 2019). However, this paper revamped all three strategies by linking pollution prevention strategy to resource commitment, product stewardship and sustainable development strategies to circular economy RL product return and product recovery. To better understand the linkage, Figure 1 shows the theoretical framework that this study proposes for automotive companies to achieve financial performance:

Figure 1 shows that automotive companies can achieve financial performance when sustainable resource commitment is being practised. Sustainable resource commitment allows companies to achieve financial performance when companies allocate resources efficiently and commit resources to retain competitive advantage. On the other hand, the CERL is divided based on RL practices of product return and product recovery that add resources back to the companies' supply chain. When RL practices are combined with the circular economy concept, it prolongs the life cycle by limiting wastage of resources such as materials, products and wastage to reduce cost and achieve better financial performance. In addition, companies' sustainable resource commitment practice will further be improved when CERL is practiced as resources, stays in the life cycle longer and when wastage is reduced. As a result, companies can allocate resources efficiently and use resources to strengthen the company's position in the industry. 


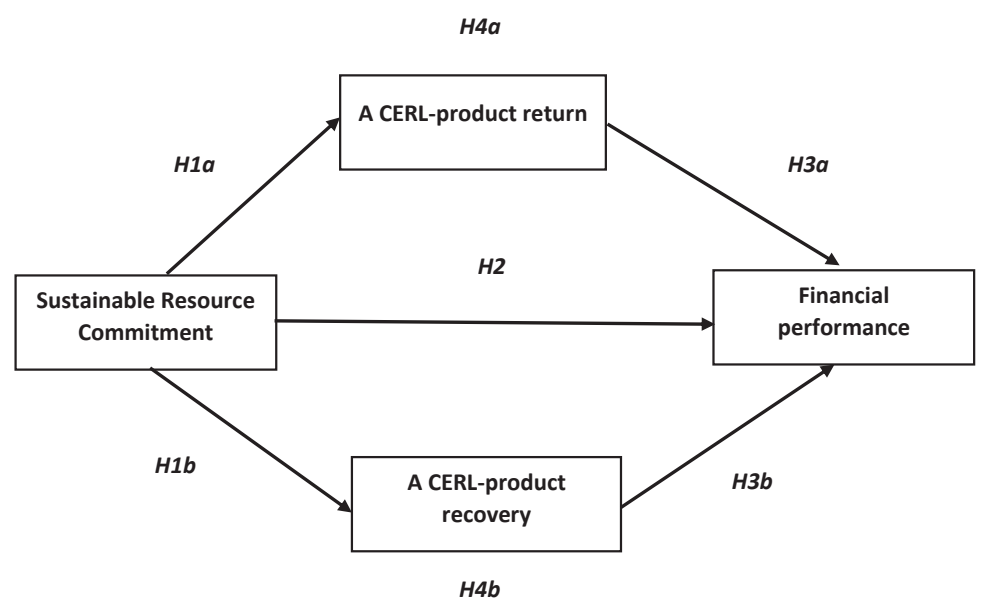

CERL-product return and recovery

95

Figure 1. Theoretical model

\section{Literature review and hypothesis development}

\subsection{Financial performance}

The critical criterion for business strategy is financial sustainability. Financial performance is the tangible outcome that maximises sales, improves profits/rising production costs and improves equity contribution and cash flow. Within the literature, revenue generated by the company's profits includes the sale of goods, or dividends, together with the sale of properties. In comparison, returns on equity combine the shareholder's net profit and cash flow that represents the transfer of equities to or from a company over a specified period. To study how financial performance is affected, scholars have considered disposal cost, reseller income, recovery of goods returned, cost of returned products and RL inventory storage and carrying expenditure in their previous studies (Maiti et al., 2020).

\subsection{Sustainable resource commitment}

Resource commitment focusses on managing and recovering essential resources (Liu et al, 2020). The contribution to resource management can be split into multiple clusters. The first cluster consists of knowledge-based resources, whilst the second cluster consists of propertybased resources (Kitano, 2020). Knowledge in inventory information (Fernando et al., 2020), technology and expert human intelligence on resource utilisation are vital inputs for organisational change (Mousa and Othman, 2020).

As per the RBV theory, Fernando et al. (2019) found that greater attention to resources improves resource commitment. Due to limited access to natural resources, companies should be highly committed to manage the resources efficiently and handle CERL-product return and recovery accordingly (Mahindroo et al., 2018). Consequently, it will contribute to the firms' financial performance. Sustainable resource commitment can help companies to reduce emissions and pollution when companies manage the resources efficiently. Hart (1995) suggested that companies practice quality improvement in the supply chain and operations to achieve sustainability goals. However, continuous improvement in the supply chain and operations alone is insufficient, as companies need to sustainably manage their resources. Therefore, it can be hypothesised as follows:

H1a. Sustainable resource commitment has a positive and significant effect on a CERLproduct return. 
EJMBE 32,1
H1b. Sustainable resource commitment has a positive and significant effect on a CERLproduct recovery.

H2. Sustainable resource commitment has a positive and significant effect on a company's financial performance.

\subsection{Reverse logistics - a cornerstone for sustainable supply chain management}

RL can be characterised as an excellent production, implementation and monitoring process that enables the cost-effective flow of raw materials, ongoing inventory and semi-finished goods from the customer to the point of origin (Rogers and Tibben-Lembke, 1999). As a result, additional value or appropriate waste disposal is made easy and required inventory for the consequent cycle is replenished (Fernando and Saththasivam, 2017). RL aims to revive interest to increase economic output and increase customer revenues and market share (Guarnieri et al., 2020).

Companies circumvent profit margin angles and align logistics in their supply chains for reduced energy usage and lower emissions under financial, socio-economic, legal and political pressures (Hopkins, 2012). Eco-friendly consumers favour brands engaged in sustainable RL activities that contribute to profitability and efficient usage of assets to meet existing requirements for mitigating environmental impacts (Marić and Opazo-Basáez, 2019). The balance between cost savings and environmental conservation has become a productive effort to boost the sustainable competitiveness of firms (Ngu et al., 2020).

RL also provides economic benefits in terms of less raw material procurement, inventory control and landfill by setting strategic locations for collection centres, reprocessing centres, remanufacturing and transportation (Ali et al., 2020). RL is becoming a critical strategic differentiator amongst organisations promoting cleaner production (Dutta et al., 2021). However, several firms face difficulties to add the recovered used goods into their current forward logistics networks. In this situation, a modern, sustainable RL supply chain network needs to be redesigned by reconstructing existing infrastructure integrated processing facilities (Gao and Cao, 2020). The CERL concept proposed in this paper directly supports these interventions.

\subsection{Circular economy}

The synthesis of circular economy and RL has importance in constructing social and economic value. Manufacturing sectors tend to pursue eco-friendly production and consumption of goods (Guarnieri et al., 2020). Companies now aim to facilitate the development and recycling of a versatile circular supply chain to reduce waste and positively impact the whole business model (Campos et al., 2017). The circular economy enables this type of business activity (Makarova et al., 2018). However, business disruptions and government policies often affect the model's performance (Shen et al., 2020).

Resource scarcity is thoroughly addressed by the industry. On that note, a CERLbased model is conceptualised in this paper that provides insights for businesses to adopt sustainability-oriented activities that can guide them to utilise the circularity of materials and manage resources efficiently. It will assist the company in reducing unnecessary costs, pollution and initiate sustainable business green growth. The concept of CERL comes from two essential notions of circular economy and RL. The circular economy and RL are different but support each other. Therefore, the circular economy can contribute to sustainable development by applying RL models related to waste recycling, value creation and customer loyalty (Dev et al., 2020). The details of the discussion are as follows: 
3.5 Circular economy-based reverse logistics

The CERL is extended to the current circular economy literature based on several criteria. The first criteria shall fit well to improve the business sustainability that focusses more on supply chain operations. The second criterion combines the complex sustainability concepts such as closed-loop supply chain and RL. The third criterion, the CERL, needs to offer better values and practical solutions to achieve sustainable competitive advantage. One of the realised ideas of sustainability incorporated in a business is RL. RL involves the management of product return and product recovery. The domains of CERL will be further discussed in the next section of this paper. Given that as justification, the circular economy's definition is still new, and scholars have called to improve the notion of circular economy (Pieroni et al., 2021).

The CERL has conceptualised the circular economy's features, including an increased life cycle, RL and a closed-loop supply chain (Figure 2). The life cycle stops at the end of the product's life, but a closed-loop supply chain will prolong the product or materials in the life cycle. At the same time, RL focusses on processing those products or materials for reintroduction in the supply chain or secondary market.

Figure 2 shows the business life cycle of a supply chain network. Nowadays, supply chain network capability is the primary criterion of comparison. Thus, Figure 2 shows the company's complete supply chain process from the supplier to the end-user. Figure 2 shows the responsibility of each supply chain process. For example, the supply process involves acquiring energy and raw material, whilst manufacturing involves designing a product and determining the production process. The distribution process involves storing products in a warehouse, monitoring product movement and the supply chain network. The logistics process is about transporting the product to the end-user.

Disposal is not a supply chain process but an outcome of product usage. If a product can be reintroduced to the supply chain, it can be reused, recycled or repaired, whilst the unusable products will be disposed of as waste. RL also enables the reintroduction of waste and creates a secondary market where companies can resell useable products. Even converted wastes

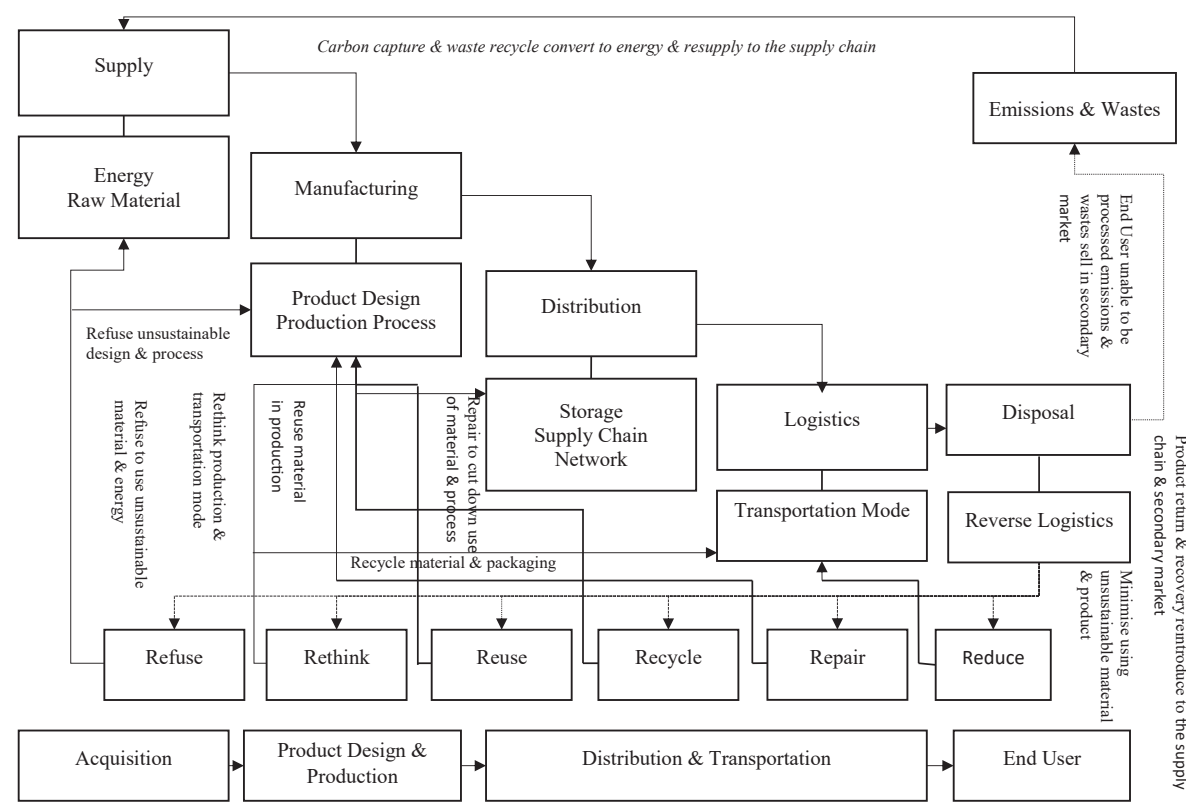

CERL-product return and recovery

Figure 2.

Circular economy RL framework 
EJMBE 32,1

98

and emissions captured through technology can be resold in another market to provide additional income. Companies can rethink their process, product design and product and eventually cut down resources in few production processes. Therefore, combining the features of a business life cycle, closed-loop supply chain and RL can improve companies' sustainable performance.

The domains of CERL are as follows:

3.5.1 CERL-product return. Product returns are detrimental financial strategies in customer sales. Most businesses project uncertain values based on product return fees and transportation charges. Product returns can lead to a loss in revenue for the company if the product is not accurately transported from the customer to the manufacturer. Hence, a company's profits and environmental efficiency can be increased through a controlled return cycle (Zaid et al., 2018) and operational performance (Fernando and Tew, 2016). Effective product returns protocols are strongly related to the concept of a circular economy that brings financial profits. This theory is in line with the NRBV principle, as the company's expertise would directly contribute to improving financial performance and competitive advantage (Baah et al., 2021).

According to NRBV theory, companies need to prolong the product life cycle and reuse materials to reduce cost. Therefore, it needs proper adoption of CERL - product return to manage and remanufacture the recycled materials for more value-added products. The companies need to design an adequate product return mechanism that makes a smooth sailing effort of repair and reuse with system integration. It will bring back the recovered product or material and save resources into the supply chain processes. This paper argued that a properly managed CERL - product return would benefit the company financially. Our argument aligns with Fernando et al. (2018) that managing product return can impact resources efficiency and financial performance. Therefore, managing product returns has a direct impact on the company's competitiveness. It is also aligned with NRBV, especially in articulating sustainable development and product stewardship strategies in environmental oriented supply chains.

NRBV has postulated that the company will gain a sustainable competitive advantage when resources are shared amongst supply chain networks to handle product returns using technology partnerships. However, it will be hard to copy the company strategy when it has integrated internal capabilities with external support from the suppliers and business partners. This justification underlies the application of product return management in the supply chain. The company needs to be committed and willing to support the efficient product return that involved sustainable internal and external resources. The stringent ELVs policy amongst the global automotive industry has driven the company to commit and optimise the sustainable resources to handle recycling and remanufacturing. Using mediating variables, Mao et al. (2016) argued that the supportive attitude of the company could be observed from the allocation level of resource commitment.

Despite the resource commitment found as a critical construct in $\mathrm{RL}$, the variations in the commitment and willingness to allocate the resource across organisations and industries have inconsistent impacts on the performance (Mahindroo et al., 2018). According to Fernando et al. (2021a, b), incorporating RBV and circular economy principles into the research model can improve the impact of environmental innovation on recycled product performance. Daugherty et al. (2005) argued that little guidance was provided on RL resource allocation. The inconsistent findings and various levels of commitment in handling product return in sustainable manners will, directly and indirectly, impact the total cost supply chain. The NRBV does not satisfactorily explain the guideline allocation of resources sharing. We argue that sustainable resource commitment is essential to drive efficient product returns and avoid fraudulent returns. The commitment to efficient resource utilisation can strengthen the relationship between the product return process and financial performance. 
The company's commitment to allocate the resources for recovery operations in reuse and remanufacturing return products can impact financial gain. The effectiveness of product return can improve the company's commitment to allocate more resources to enhance financial performance. This study argues that effective product return management as an intervening variable can improve company commitment to using the resource wisely, which lead to financial gain. Sustainable resource commitment can drive innovativeness, cost reduction and firm longevity. In this regard, the study contends that the company can improve their commitment to utilise sustainable resources through CERL-product return and recovery procedures. Therefore, it can be hypothesised that:

H3a. A CERL-product return has a positive and significant effect on the company's financial performance.

H4a. A CERL-product return mediates the relationship between sustainable resource commitment and the company's financial performance.

3.5.2 CERL-product recovery. In congruence with the rising environmental problems and related costs (Fernando et al., 2017), the Government stresses the manufacturing sector to recover and reuse materials, especially those at the end of their life span. It is made possible by the industrial revolution and technology development (Govindan and Soleimani, 2017). Restoration of products also extends the product life cycle by saving money and capital (Chen et al., 2017). Product recovery services may be described as the manufacturing process flow dedicated to recovering redundant components, parts and products (Thierry et al., 1995). Thus, product recovery is aimed at increasing environmental values and reducing waste.

Six recovery methods are used, including reuse, repair, refurbishment, renovation, retrofitting and commercialisation (Vijayaraghavan et al., 2013). Recycling is the best way of recovering the product by acquiring and reselling redundant components, parts or products for use on the market (Fernando et al., 2017). Recovery activities have the potential to significantly enhance financial performance (Garg et al., 2015). Product recovery-related constructs are the lifeline of a circular business model. Based on the concept of NRBV, a CERL-product recovery will strengthen the relationship between the company's commitment to using green-based resources and financial performance. NRBV theory posits that a CERLproduct recovery is in line with sustainable development and product stewardship strategies. This understanding comes from how companies manage the sustainable resource and less dependency on natural resources. CERL-product recovery will assist the company in keeping the scrap and undamaged materials within the closed-loop supply chain. The product recovery needs to be designed as part of a business strategy compatible with supply chain networks.

The company can improve its financial performance when integrating the CERL-product recovery through supply chain networks. In addition, the company has committed to using environmental-friendly materials and resources obtained efficiently through CERL-product recovery can impact the financial outcomes. It will save more cost and turn waste into valuable products. Li (2014) found that resource commitment has positively mediated the linkage between environmental innovation practices and financial performance.

The CERL drives the company commitment to utilise sustainable resources for competitiveness. This study argues that a company's internal capability can be improved if the company has committed to sustainable resources in the supply chain for operational efficiency. It is argued that RL is hard to achieve when the company is unwilling to utilise sustainable resources. The company needs to commit and modify their supply chain processes to achieve profitability (Fernando and Tew, 2016). Companies can gain and maintain a competitive advantage when successful collaboration exists amongst business networks. 
EJMBE 32,1

100

The product recovery process is complex and fraught with difficulties. The company's commitment to allocating resources is a critical enabler of successful product recovery. Company performance can be determined by co-creating value with adequate collaborative resources (Sinkovics et al.,2018). To ensure that the product recovery quality is comparable to that of new products, companies must expend significant effort and resources, particularly in the areas of cannibalisation, repair, refurbishment and remanufacture product return (Zhao et al., 2021). Unfortunately, the product return and recovery process continue to be a critical issue affecting financial performance (Ambilkar et al., 2021). Sinkovics et al. (2018) found that RBV-based competency mediated RL commitment, innovative abilities and manufacturer performance. However, to the best of our knowledge, there is little evidence in the literature on how resource commitment can improve the relationship between product recovery and financial performance. It is argued that managing a sustainable resource plays a mediating role in fostering a positive effect on product recovery efficiency and financial outcomes.

This paper argued that a company would regain the lost value of scrap when the product recovery was successfully conducted. The company will enhance its commitment to using sustainable resources and be less dependent on natural resources when the financial performance improves. However, if it is not adequately managed, the reuse of materials for product recovery has its own risk, like a product that breaks quickly and impacts its brand image. Typically, the company is unwilling to commit when the sustainable efforts do not affect the financial return. The mediating effect of product recovery will enhance the company committed to utilising the CERL methods of sustainable resources to improve financial performance. Therefore, it can be hypothesised that if the product recovery helps companies to obtain resources efficiently, it improves resource commitment:

H3b. A CERL-product recovery has a positive and significant effect on financial performance.

H4b. A CERL-product recovery mediates the relationship between sustainable resource commitment and the company's financial performance.

\section{Methods}

This study adopted a cross-sectional and survey method that was applicable for the required analysis. In this study, the target population was the companies directly or indirectly involved in the Malaysian automotive supply chain. The study sample was taken from the MATRADE (2020). Specifically, the sample frame was from the automotive parts and components section of the database. A total of 616 companies that were identified seemed relevant for this study. Malaysian automotive companies were chosen as a sample due to the ability to comply with environmental management standard (ISO 14001:2015).

For the selected sample, the research unit was the organisation. The selected respondents held management roles in each organisation with sufficient expertise and information to serve their respective companies. In addition, they were selected for their knowledge in implementing RL practices such as inventory recovery, returns, merchandising approval and international certification (ISO standards). This study uses a stratified sampling approach since the characteristics of the population were heterogeneous.

Some efforts have been conducted to control the risk of biases. The data collection was conducted within three weeks with anonymous feedback from respondents. The cut-off duration between early responses in the survey is a week and the rest were considered late. There is no mean value difference between early and late responses in the survey ( $p$-value $>$ 0.05) based on non-response bias results (Table 1). The measurement indicators for the survey have been adapted from existing scholarly work (Table 2). It ensures that the content 
is accurate, reliable and correctly structured to avoid inaccurate documentation of responses. The measurement relating to the financial performance was adapted from Lai et al. (2013), whilst resource commitment-based measurement items have been adapted from Richey et al. (2014).
CERL-product return and recovery

\begin{tabular}{|c|c|c|c|c|c|c|c|c|c|}
\hline \multirow[b]{2}{*}{ Variable } & \multicolumn{2}{|c|}{ Mean (SD) } & \multicolumn{2}{|c|}{$\begin{array}{l}\text { Std error } \\
\text { mean }\end{array}$} & \multirow[b]{2}{*}{$p$-value (remarks) } & \multirow[b]{2}{*}{ FP } & \multicolumn{2}{|c|}{ HTMT } & \multirow[t]{2}{*}{101} \\
\hline & G1 & G2 & G1 & G2 & & & PR & PRT & \\
\hline FP & $3.895(0.485)$ & $4.113(0.364)$ & 0.101 & 0.038 & $0.183(\mathrm{NS})$ & & & & \\
\hline PR & $3.895(0.478)$ & $4.097(0.398)$ & 0.099 & 0.041 & 0.372 (NS) & 0.640 & & & Tabb 1 \\
\hline PRT & $3.891(0.464)$ & $4.094(0.369)$ & 0.096 & 0.038 & 0.236 (NS) & 0.712 & 0.837 & & $\begin{array}{l}\text { Iable } \\
\text { esponse bi }\end{array}$ \\
\hline $\mathrm{RC}$ & $3.884(0.477)$ & $4.044(0.538)$ & 0.099 & 0.056 & 0.810 (NS) & 0.561 & 0.479 & 0.668 & $\begin{array}{r}\text { Non-response bias } \\
\text { results and }\end{array}$ \\
\hline \multicolumn{9}{|c|}{$\begin{array}{l}\text { Note(s): } G 1=\text { early response }(n=23) ; G 2=\text { late response }(n=90) ; \mathrm{SD}=\text { Std deviation; } p \text {-value: }>0.50 ; \mathrm{NS}= \\
\text { not significant; HTMT }<0.85 ; \mathrm{RC}=\text { resource commitment; } \mathrm{PRT}=\text { product return; } \mathrm{PR}=\text { product recovery and } \\
\text { FP = financial performance }\end{array}$} & $\begin{array}{l}\text { discriminant validity: } \\
\text { heterotrait-monotrait } \\
\text { ratio (HTMT) }\end{array}$ \\
\hline
\end{tabular}

\begin{tabular}{|c|c|c|c|c|c|c|}
\hline Construct & Item & Indicator & Loadings & CR & AVE & \\
\hline \multirow{5}{*}{$\begin{array}{l}\text { Financial } \\
\text { performance }\end{array}$} & FP1 & Decrease of disposal costs & 0.776 & \multirow[t]{5}{*}{0.917} & \multirow[t]{5}{*}{0.688} & \\
\hline & FP2 & Increase of revenue from the resale & 0.830 & & & \\
\hline & FP3 & $\begin{array}{l}\text { Effective in handling recovery of assets related to } \\
\text { our returned products }\end{array}$ & 0.859 & & & \\
\hline & FP4 & $\begin{array}{l}\text { Effective in handling cost containment related to } \\
\text { our returned products }\end{array}$ & 0.839 & & & \\
\hline & FP5 & Reduction of inventory investment & 0.842 & & & \\
\hline \multirow[t]{5}{*}{$\begin{array}{l}\text { Product } \\
\text { recovery }\end{array}$} & PR1 & $\begin{array}{l}\text { Our company designs the product to be easy to } \\
\text { recycle }\end{array}$ & 0.831 & \multirow[t]{5}{*}{0.919} & \multirow[t]{5}{*}{0.696} & \\
\hline & PR2 & Our company establishes recycling procedures & 0.810 & & & \\
\hline & PR3 & $\begin{array}{l}\text { Our company establishes appropriate procedures } \\
\text { for dangerous or contaminated materials at the end } \\
\text { of the product's life cycle }\end{array}$ & 0.914 & & & \\
\hline & PR4 & $\begin{array}{l}\text { Our company uses biodegradable content materials } \\
\text { for packaging }\end{array}$ & 0.718 & & & \\
\hline & PR5 & $\begin{array}{l}\text { Our company reuses materials from used products } \\
\text { or components }\end{array}$ & 0.885 & & & \\
\hline \multirow[t]{6}{*}{ Product return } & PRT1 & $\begin{array}{l}\text { Collects back used products from customers for } \\
\text { recycling, reclamation of materials or reuse }\end{array}$ & 0.744 & \multirow[t]{6}{*}{0.917} & \multirow[t]{6}{*}{0.650} & \\
\hline & PRT2 & $\begin{array}{l}\text { Collects back used packaging from customers for } \\
\text { reuse or recycling }\end{array}$ & 0.816 & & & \\
\hline & PRT3 & $\begin{array}{l}\text { Requires suppliers to collect back their packaging } \\
\text { materials }\end{array}$ & 0.778 & & & \\
\hline & PRT4 & $\begin{array}{l}\text { Returns its products to suppliers for recycling, } \\
\text { retaining of materials or remanufacturing }\end{array}$ & 0.865 & & & \\
\hline & PRT5 & $\begin{array}{l}\text { Returns its packaging to suppliers for reuse or } \\
\text { recycling }\end{array}$ & 0.849 & & & \\
\hline & PRT6 & Returns the products from customers for a safe refill & 0.778 & & & \\
\hline \multirow[t]{3}{*}{$\begin{array}{l}\text { Resource } \\
\text { commitment }\end{array}$} & $\mathrm{RC} 1$ & $\begin{array}{l}\text { Level of technological resource commitment to } \\
\text { reverse logistics within your company }\end{array}$ & 0.823 & \multirow[t]{3}{*}{0.900} & \multirow[t]{3}{*}{0.751} & \\
\hline & $\mathrm{RC} 2$ & $\begin{array}{l}\text { Level of managerial resource commitment to } \\
\text { reverse logistics within your company }\end{array}$ & 0.896 & & & \multirow{2}{*}{$\begin{array}{r}\text { Table } 2 . \\
\text { Convergent validity of } \\
\text { measurement } \\
\text { indicators }\end{array}$} \\
\hline & $\mathrm{RC} 3$ & $\begin{array}{l}\text { Level of financial resource commitment to reverse } \\
\text { logistics within your company }\end{array}$ & 0.879 & & & \\
\hline
\end{tabular}


EJMBE 32,1

102

On the other hand, measurement items for RL were adapted from Fernando and Tew (2016). The initial survey was pre-tested with ten manufacturers from the automobile industry. This is to ensure that respondents did not have difficulties in understanding any of the question items. Furthermore, their opinions were not included in the final data collection to avoid any bias. IBM SPSS version 25 and partial least squares structural equation modeling (PLS-SEM) version 3.3.7 have been applied to data processing once the data have been collected.

\subsection{Database}

A set of 616 questionnaires was propagated through an Internet-based survey based on the list of organisations listed in the repositories. Of the total of 616 questionnaires issued, 113 were returned, for an $18.34 \%$ response rate. Many factors affected this response rate, including the respondents were busy with the coronavirus disease-2019 (COVID-19) recovery stage. The survey was distributed through the Internet, which usually has a lower-response rate than hand-delivered instruments. None of the survey questions was unfinished, as the electronic survey has an option to make all questions mandatory to be answered before the respondent can proceed to the next section. Out of the 113 companies that replied, $47.8 \%$ (54 companies) were foreign-owned multinational corporations (MNCs). The size of the organisation was determined by the number of employees in the company. Large corporations (500 employees) constituted the largest category of respondents with 67 companies $(59.3 \%)$. The response rate and the balance distributed in this survey show that this study can represent the Malaysian automotive industry and provide empirical evidence of CERL in Malaysia.

\subsection{Variables and method of analysis}

Even though respondents' acceptable response rate and demographic profile were achieved, the empirical data must comply with the goodness of measures to prove that the data are valid and reliable. The validity and reliability of data are essential to ensure that the finding aligns with the existing theory. Reliability and convergence validity tests were performed through statistical software SmartPLS version 3.3.3. The reliability indicators to prove that the data are reliable and valid are the composite reliability $(\mathrm{CR})$ value, factor loadings value and average variance value extracted (AVE). Hair et al. (2019) postulated that the cut-off value of CR should be above 0.7 .

Thus, the acceptable cut-off value ensures that the data has achieved $70 \%$ or more reliability value. Hair et al. (2019) proposed that the cut-off value for factor loading and AVE are above 0.5 or should achieve more than $50 \%$ reliability and validity thresholds. Table 2 shows the construct AVE and CR values that are more than the cut-off value whilst the factor loading values for each indicator exceed 0.5 cut-off value.

As a result, the data have been shown to meet the convergence validity criteria. Other than convergence validity, the data have to be tested for discriminant validity. Discriminant validity will prove that the measurement indicators were distinguished in each construct. Hair et al. (2019) recommended heterotrait-monotrait (HTMT) criterion as a test of discriminatory validity. The discriminant validity has examined the consistency of solid connection between reflective construct and its indicators in variance-based structural equations modelling (Hair et al., 2022). Henseler et al. (2015) postulated that HTMT is a robust test to examine the discriminant validity in composite and factor-based modelling.

The model value was below 0.85 , and the discriminatory validity of the two reflective structures was calculated as the results were consistent with Henseler et al.'s (2014) rule of thumb (Table 1). Although the correlation between product return and product recovery is high (HTMT: 0.837), our results show that the ratio of correlations criterion between product return and product recovery is within the acceptable cut-off value (HTMT: 0.85). The results 
suggest that the variables comprehended and distinguished each research construct. It is argued that there is not enough evidence to conclude that the correlation across latent constructs and indicators is too high and not distinguishable. As a result, we can conclude that discriminant validity has been established.

CERL-product return and recovery

\section{Results}

\subsection{Hypothesis testing}

This paper has proposed hypotheses based on a theoretical framework (Figure 1). Based on the Malaysian perspective, the findings of these hypotheses are shown in Table 3. Hypothesis H1a suggests that sustainable resource commitment will have a positive and significant impact on CERL-product return. The H1a results showed that the path was significant at $p<0.001$ ( $\beta$-path coefficient $=0.764$ and $t$-value $=10.592)$. As a result, Hla was accepted.

$\mathrm{H} 1 \mathrm{~b}$ expected that sustainable resource commitment has a positive and significant effect on the CERL-product recovery. The tests showed that H1b was statistically significant at $p<0.001$ ( $\beta$-path coefficient $=0.600$ and $t$-value $=8.342$ ). Hypothesis $\mathrm{H} 2$ stated that sustainable resource commitment has a positive and significant relationship to financial performance. However, the finding shown in $\mathrm{H} 2$ was statistically negligible at $p>0.050$ ( $\beta$-path coefficient $=0.055$ and $t$-value $=1.308)$; thus, the $\mathrm{H} 2$ hypothesis was rejected.

H3a suggested that CERL return on the product would positively and significantly relate to financial performance. The result showed that $\mathrm{H} 3 \mathrm{a}$ a was statistically significant at $p<0.001$ and positively related ( $\beta$-path coefficient $=0.729$ and $t$-value $=10.271)$. Thus, the H3a hypothesis was approved. Hypothesis H3b indicated that CERL-product recovery has a positive and significant relationship to financial performance. The analysis revealed that $\mathrm{H} 3 \mathrm{~b}$ was statistically significant at $p<0.001$, and the recovery of the product was strongly and positively related to financial performance ( $\beta$-path coefficient $=0.431$ and $t$-value $=6.519$ ). Hypothesis H3a was then accepted.

Table 3 examined CERL-product return and recovery variables' mediating effect for statistical significance at $p<0.001$. H4a was established as the CERL-product's return substantially mediates the path from sustainable resource commitment to financial performance $(\beta$-path coefficient $=0.557$ and $t$-value $=7.276)$. Additionally, H4b of CERLproduct recovery was accepted as a mediating variable between sustainable resource commitment and its financial performance as the $t$-value was 2.781 and 0.140 for the $\beta$-path coefficient. The $R^{2}$ value is analysed to determine the scale of the effect $\left(f^{2}\right)$. The $R^{2}$ value for financial results is 0.925 , the product recovery is 0.584 and the product return is 0.360 .

The $R^{2}$ value shows that the sustainable resource commitment construct explained $92 \%$ of companies' financial performance whilst achieving 58 and 36\%, respectively, for CERLproduct recovery and CERL-product return. Thus, there was sufficient evidence that the hypotheses developed represented companies' sustainable resource commitment towards financial performance, CERL-product recovery and CERL-product return.

Furthermore, this paper also reported the effect size of the $R^{2}$. Whilst $R^{2}$ explained the effect of independent variables on explaining the dependent variable, $f^{2}$ on the other hand, measured the strength of the relationship provided by $R^{2}$. This study followed Cohen (1988) guideline on the size of the effect. The results showed that the effect size values $\left(f^{2}\right)$ were sufficient to support the hypotheses strength. Table 3 demonstrates the predictive relevance $\left(Q^{2}\right)$ of the structural model using the blindfolding technique. The $Q^{2}$ analysis was provided by SmartPLS statistical software to determine the relevancy of the proposed theoretical framework. According to Hair et al. (2019), the cut-off value of $Q^{2}$ is predicted to exceed zero. The cut-off value was found to be more than zero. Therefore, the results suggest that all three predictive relevance values provide ample evidence to claim that the model has adequate predictive relevance. 
EJMBE

32,1

104

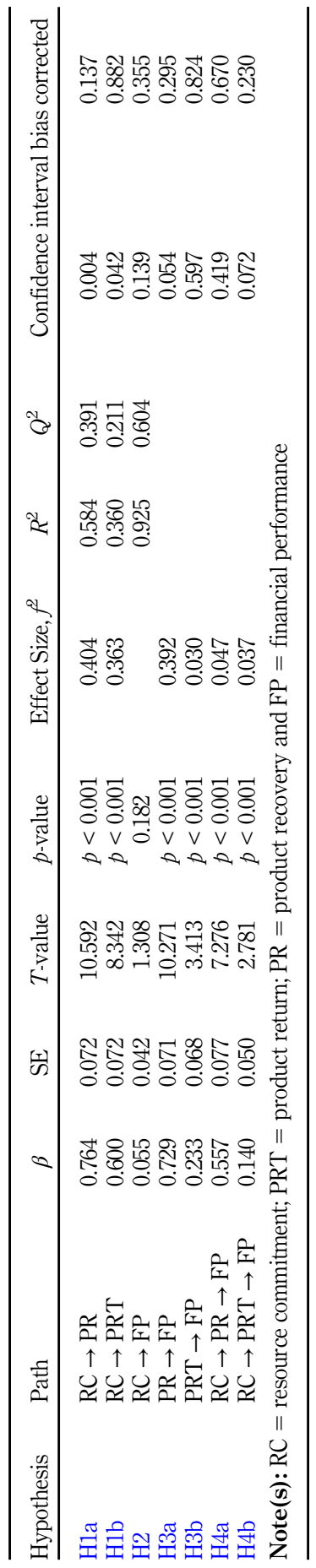

Table 3.

Summary of

hypotheses testing of initial PLS path model 
5.2 Importance-performance map analysis

This study was guided by Ringle and Sarstedt (2016) in examining the output level of latent and dependant variables in the PLS-SEM review. IPMA is useful for corporate decisions, as it offers a deeper understanding of market domain prioritisation. This is because IPMA can recognise the most critical practices for improving financial results; both scholars and practitioners can establish business strategies to improve their performance. Table 4 shows that financial performance has a latent variable index value of 4,068 and a score of 69,796 for resource commitment. Table 5 and Figure 3 show the importance-performance of the indicators. The IPMA result could be divided into four quadrants. The top left quadrant is of high importance but low performance, whilst the bottom left quadrant denotes low importance and low performance. On the other hand, the top right quadrant denotes high

\begin{tabular}{lrrrr}
\hline & FP & PR & \multicolumn{1}{c}{ PRT } & RC \\
\hline LV index values & 4.068 & 4.056 & 4.052 & 4.017 \\
LV performance & 55.917 & 55.651 & 54.925 & 69.796
\end{tabular}

Note(s): $\mathrm{RC}=$ resource commitment; $\mathrm{PRT}=$ product return; $\mathrm{PR}=$ product recovery; $\mathrm{FP}=$ financial performance and $\mathrm{LV}=$ latent variable

CERL-product return and recovery

105

Table 4

Latent variable index values and performance of the target construct FP

\begin{tabular}{cccc}
\hline & PR & PRT & RC \\
\hline 1 & $0.176(69.322)$ & $0.047(68.732)$ & $0.251(66.962)$ \\
2 & $0.165(54.425)$ & $0.052(54.867)$ & $0.336(68.437)$ \\
3 & $0.191(53.097)$ & $0.058(50.885)$ & $0.279(74.336)$ \\
4 & $0.161(50.885)$ & $0.046(52.655)$ & \\
5 & $0.180(51.77)$ & $0.048(55.212)$ & \\
6 & & $0.038(51.212)$ &
\end{tabular}

Note(s): Values in parentheses are indicators' performance; $\mathrm{RC}=$ resource commitment; PRT = product return; $\mathrm{PR}=$ product recovery; $\mathrm{FP}=$ financial performance

Table 5.

Indicators' importance and performance of predictors to the targeted construct

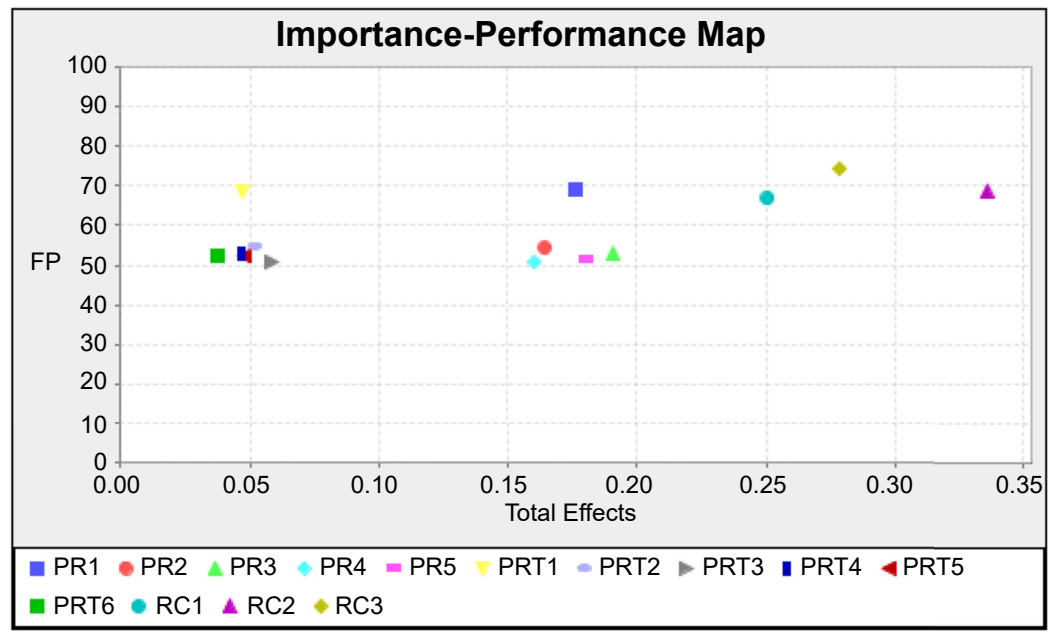

Figure 3.

Importanceperformance map 
EJMBE 32,1

\section{6}

importance and high performance, whilst the bottom right quadrant has low importance but high performance. Thus, Figure 3 shows that RCR3 and PR1 have high importance and high performance.

Due to limited access to natural resources, companies should be highly committed to manage the resources efficiently and handle CERL-product return and recovery accordingly (Mahindroo et al., 2018).

\section{Discussion}

The impact of a sustainable resource commitment on CERL has been significant in achieving financial performance. Using CERL, automotive companies can optimise the use of materials by restoration activities and meet the environmental objectives. In addition, resource commitment can drive efficient and productive product return and recovery management. This study showed that CERL has a significant impact on financial performance (Saxena et al., 2018). The finding further suggests that the automotive industry can increase its financial performance by investing further in remanufacturing, refurbishment or recycling, creating new opportunities and niche markets maintaining the same environmental quality standards (Fernando et al., 2018).

Furthermore, this study found that the greater the resource commitment, the greater are the financial performance. Our finding is in line with Mahindroo et al. (2018). On the other hand, our result found not enough evidence to prove that resource commitment directly affects financial performance. The finding is in contrast with Sinkovics et al. (2018). Overall, our results show that the circular economy helps businesses improve efficiency, especially with RL. Hence, the proposed theoretical model is embraced with the use of CERL. In regard to mediating role in the research model, we found that sustainable resource commitment has mediated the relationship between CERL and financial performance. Our findings are consistent with those of Daugherty et al. (2005).

The CERL concept proposed in this study would help gain insights into the process management of market players and help design supply chains of great value achieved through waste reduction (Marić and Opazo-Basáez, 2019). Awareness of the circular economy has also seen a rising trend amongst the industry. However, given the significant changes in our natural habitat and ecosystems, stakeholders and government bodies should expand their operations to include circular economy-based concepts that target the right infrastructure, services, and skills in logistics, procurement, distribution and training. The Malaysian automotive sector and related public bodies and stakeholders should derive insights from these ideas and put them into practice. This study opens several pathways with the help of the proposed CERL model.

\section{Implications}

Nowadays, it is challenging to retain competitive advantage or consistently achieve performance when environmental and technological advancements are the centre of attention in the current business environment. Therefore, we discussed both the theoretical and practical implications of our findings separately.

\subsection{Theoretical implications}

This study has also expanded NRBV theory to improve financial sustainability with a commitment to internal resources. The circularity concept in RL has led to an increase a strategic advantage for the automobile industry. In other words, a company should optimise the use of resources for sustainable growth. The adoption of the CERL program, in particular, reduces energy use, scraps and raw material used in the automotive industry and indirectly 
improves the overall environment efficiency, which benefits all stakeholders. Work using NRBV theory shows that it is possible to extend the theory since NRBV states that sustainable resource commitment and sustainability practices can improve financial performance.

CERL-product return and recovery

\subsection{Practical implications}

The dynamic market, especially in the automotive industry, means that companies concentrating on assets without stressing the value of environmental concerns have no competitive edge. From the company's point of view, additional revenue would be created if CERL activities were to meet the requirements to accomplish the social responsibilities. Government officials should use a win-win of $\mathrm{CE}$ to build and manage a more green and sleek production market that promotes political legislation (Korhonen et al., 2018). Resource and production based on waste management and life-cycle policies can be framed according to demographic parameters. Even though current policies depend too heavily on government subsidies, they should benefit from production and market governance (Zhu et al., 2019).

Industrial wastes, especially in developed countries, are severely controlled. New options for controlling demand have been created for zero-waste initiatives to eliminate waste creation and manage trash (Das et al., 2019). This study portrays thoughtful, practical implications from which policymakers and government organisations can derive insights, especially in governing the automotive sector. Therefore, the CERL model proposed by the product return and recovery protocol positively and significantly affects the company's financial performance and significantly mediates the relationship between sustainable resource commitment and its financial performance.

\section{Conclusion}

To conclude, most companies' financial performance is affected by economic downturns, but RL offers a solution by generating additional revenues to support the company. This is the benefit of the inclusion of a circular economy and its processes that can create value. Therefore, the circular economy permits the development of the circular supply chain and is responsible for environmentally friendly practices. During the economic recession and COVID-19 pandemic, the operations of automobile manufacturing companies are reduced because of lower demand or technological disruption due to lower competition for replaced parts or components.

In this case, better understanding and proper management on how to use existing infrastructure, machinery and equipment to increase production through the use of RL or to extend business lines to a specific segment of the market, such as the resale to the secondary market of used replacement parts and components, would surely allow a company to cope with any downturns. A closer look into other returns and recovery management approaches that are related to remanufacturing in the automotive industry is required. The study only deals with the global product return and recovery in the automotive sector. In future research, this CERL model as proposed has good scope to be explored in automation systems and new sustainable metrics of sustainable supply chains. Further work on the development of strategic circular business models based on concepts of circular economy and Industry 4.0 should be undertaken swiftly. The company is suggested to adopt Blockchain technology to monitor the traceability of carbon emission and integrity of green practices in the supply chain (Fernando et al., 2021a, b). Value creation through a circular economy that runs through all directions into a winning business model should be tested empirically in all business sectors. 
EJMBE 32,1

\section{References}

Abbas, H. and Farooquie, J.A. (2020), "Reverse logistics practices in Indian pharmaceutical supply chains: a study of manufacturers", International Journal of Logistics Systems and Management, Vol. 35, pp. 72-89.

Ali, S.S., Paksoy, T., Torgul, B. and Kaur, R. (2020), "Reverse logistics optimisation of an industrial air conditioner manufacturing company for designing sustainable supply chain: a fuzzy hybrid multi-criteria decision-making approach”, Wireless Networks, Vol. 26 No. 8, pp. 5759-5782.

Ambilkar, P., Dohale, V., Gunasekaran, A. and Bilolikar, V. (2021), "Product returns management: a comprehensive review and future research agenda", International Journal of Production Research, in press, pp. 1-25.

Autry, C.W., Daugherty, P.J. and Richey, R.G. (2001), "The challenge of reverse logistics in catalog retailing", International Journal of Physical Distribution and Logistics Management, Vol. 31 No. 1, pp. 26-37.

Baah, C., Opoku-Agyeman, D., Acquah, I.S.K., Agyabeng-Mensah, Y., Afum, E., Faibil, D. and Abdoulaye, F.A.M. (2021), "Examining the correlations between stakeholder pressures, green production practices, firm reputation, environmental and financial performance: evidence from manufacturing SMEs", Sustainable Production and Consumption, Vol. 27, pp. 100-114.

Barney, J. (1991), "Firm resources and sustained competitive advantage", Journal of Management, Vol. 17, pp. 99-120.

Batista, L., Bourlakis, M., Smart, P. and Maull, R. (2018), "In search of a circular supply chain archetype-a content-analysis-based literature review”, Production Planning and Control, Vol. 29 No. 6, pp. 438-451.

de Campos, E.A.R., de Paula, I.C., Pagani, R.N. and Guarnieri, P. (2017), "Reverse logistics for the endof-life and end-of-use products in the pharmaceutical industry: a systematic literature review", Supply Chain Management: An International Journal, Vol. 22, pp. 375-392.

Chan, C.K., Man, N., Fang, F. and Campbell, J.F. (2020), "Supply chain coordination with reverse logistics: a vendor/recycler-buyer synchronised cycles model”, Omega, Vol. 95, p. 102090.

Chen, X., Luo, Z. and Wang, X. (2017), "Impact of efficiency, investment, and competition on low carbon manufacturing", Journal of Cleaner Production, Vol. 143, pp. 388-400.

Centre for Remanufacturing and Reuse (CRR) (2015), "Remanufacturing in Malaysia an assessment of the current and future", APEC Report, Vol. 57 No. 1, pp. 1-57.

Cohen, J. (1988), Statistical Power Analysis, 2nd ed., Erlbaum, Hillsdale, NJ.

Das, S., Lee, S.-H., Kumar, P., Kim, K.-H., Lee, S.S. and Bhattacharya, S.S. (2019), "Solid waste management: scope and the challenge of sustainability", Journal of Cleaner Production, Vol. 228, pp. 658-678.

Daugherty, P.J., Richey, R.G., Genchev, S.E. and Chen, H. (2005), "Reverse logistics: superior performance through focused resource commitments to information technology", Transportation Research Part E: Logistics and Transportation Review, Vol. 41 No. 2, pp. 77-92.

Davcik, N.S. and Sharma, P. (2016), "Marketing resources, performance, and competitive advantage: a review and future research directions", Journal of Business Research, Vol. 69 No. 12, pp. $5547-5552$.

de Campos, E.A.R., de Paula, I.C., Ten Caten, C.S., Maçada, A.C.G., Marôco, J. and Ziegelmann, P.K. (2020), "The effect of collaboration and IT competency on reverse logistics competencyEvidence from Brazilian supply chain executives", Environmental Impact Assessment Review, Vol. 84, p. 106433.

Dev, N.K., Shankar, R. and Qaiser, F.H. (2020), "Industry 4.0 and circular economy: operational excellence for sustainable reverse supply chain performance", Resources, Conservation and Recycling, Vol. 153, p. 104583. 
Dutta, P., Talaulikar, S., Xavier, V. and Kapoor, S. (2021), "Fostering reverse logistics in India by prominent barrier identification and strategy implementation to promote circular economy", Journal of Cleaner Production, Vol. 294 No. 126241, pp. 1-16.

Fernando, Y. and Saththasivam, G. (2017), "Green supply chain agility in EMS ISO 14001 manufacturing firms: empirical justification of social and environmental performance as an organisational outcome", International Journal of Procurement Management, Vol. 10, pp. 51-69.

Fernando, Y. and Tew, M.M. (2016), "Reverse logistics in manufacturing waste management: the missing link between environmental commitment and operational performance", International Journal of Integrated Supply Management, Vol. 10, p. 264.

Fernando, Y., Sharon, S.S.T.S.S.T., Wahyuni-Td, I.S.I.S. and Tundys, B. (2017), "The effects of reverse logistics on cost control abilities: an insight into manufacturing companies in Malaysia", International Journal of Value Chain Management, Vol. 8, pp. 285-306.

Fernando, Y., Walters, T., Ismail, M.N., Seo, Y.W. and Kaimasu, M. (2018), "Managing project success using project risk and green supply chain management", International Journal of Managing Projects in Business, Vol. 11 No. 2, pp. 332-365.

Fernando, Y., Jabbour, C.J.C. and Wah, W.X. (2019), "Pursuing green growth in technology firms through the connections between environmental innovation and sustainable business performance: does service capability matter?", Resources, Conservation and Recycling, Vol. 141, pp. 8-20.

Fernando, Y., Abideen, A.Z. and Shaharudin, M.S. (2020), "The nexus of information sharing, technology capability and inventory efficiency", Journal of Global Operations and Strategic Sourcing, Vol. 33 No. 4, pp. 327-351.

Fernando, Y., Tseng, M.L., Sroufe, R., Abideen, A.Z., Shaharudin, M.S. and Jose, R. (2021a), "Eco-innovation impacts on recycled product performance and competitiveness: Malaysian automotive industry", Sustainable Production and Consumption, Vol. 28, pp. 1677-1686.

Fernando, Y., Rozuar, N.H.M. and Mergeresa, F. (2021b), "The blockchain-enabled technology and carbon performance: insights from early adopters", Technology in Society, Vol. 64, p. 101507.

Gao, X. and Cao, C. (2020), "A novel multi-objective scenario-based optimisation model for sustainable reverse logistics supply chain network redesign considering facility reconstruction", Journal of Cleaner Production, Vol. 270, p. 122405.

Garg, K., Kannan, D., Diabat, A. and Jha, P.C. (2015), "A multi-criteria optimisation approach to manage environmental issues in closed loop supply chain network design", Journal of Cleaner Production, Vol. 100, pp. 297-314.

Geissdoerfer, M., Morioka, S.N., de Carvalho, M.M. and Evans, S. (2018), "Business models and supply chains for the circular economy”, Journal of Cleaner Production, Vol. 190, pp. 712-721.

Giampieri, A., Ling-Chin, J., Ma, Z., Smallbone, A. and Roskilly, A.P. (2020), "A review of the current automotive manufacturing practice from an energy perspective”, Applied Energy, Vol. 261, p. 114074.

Govindan, K. and Soleimani, H. (2017), "A review of reverse logistics and closed-loop supply chains: a Journal of Cleaner Production focus", Journal of Cleaner Production, Vol. 142, pp. 371-384.

Guarnieri, P., Cerqueira-Streit, J.A. and Batista, L.C. (2020), "Reverse logistics and the sectoral agreement of packaging industry in Brazil towards a transition to circular economy", Resources, Conservation and Recycling, Vol. 153, p. 104541.

Hair, J.F., Risher, J.J., Sarstedt, M. and Ringle, C.M. (2019), "When to use and how to report the results of PLS-SEM", European Business Review, Vol. 31 No. 1, pp. 2-24.

Hair, J.F., Jr., Hult, G.T.M., Ringle, C.M. and Sarstedt, M. (2022), A Primer on Partial Least Squares Structural Equation Modeling (PLS-SEM), 3rd ed., Sage Publications, California.

Hart, S.L. (1995), "A natural-resource-based view of the firm", Academy of Management Review, Vol. 20 No. 4, pp. 986-1014. 
EJMBE 32,1

\section{0}

Henseler, J., Ringle, C.M. and Sarstedt, M. (2015), “A new criterion for assessing discriminant validity in variance-based structural equation modeling", Journal of the Academy of Marketing Science, Vol. 43 No. 1, pp. 115-135.

Henseler, J., Dijkstra, T.K., Sarstedt, M., Ringle, C.M., Diamantopoulos, A., Straub, D.W., Ketchen, D.J., Hair, J.F., Hult, T.M. and Calantone, R.J. (2014), "Common beliefs and reality about PLS: comments on Rönkkö and Evermann (2013)”, Organizational Research Methods, Vol. 17 No. 2, pp. 182-209.

Hofmann, F.M. and Visagie, S.E. (2020), "Choosing reverse logistics channel structures for the return of end-of-life products", Journal of Remanufacturing, Vol. 10 No. 3, pp. 239-258.

Hopkins, M. (2012), The Planetary Bargain: Corporate Social Responsibility Matters, 2nd ed., Routledge, London.

Jonkute, G. and Staniškis, J.K. (2016), "Realising sustainable consumption and production in companies: the sustainable and responsible company (SURESCOM) model", Journal of Cleaner Production, Vol. 138, pp. 170-180.

Julianelli, V., Caiado, R.G.G., Scavarda, L.F. and Cruz, S.P.D.M.F. (2020), "Interplay between reverse logistics and circular economy: critical success factors-based taxonomy and framework", Resources, Conservation and Recycling, Vol. 158, p. 104784.

Kirchoff, J.F., Tate, W.L. and Mollenkopf, D.A. (2018), "Resource commitment and sustainability: a reverse logistics performance process model", International Journal of Physical Distribution and Logistics Management, Vol. 48, pp. 164-182.

Kitano, S. (2020), "Formation factors and effects on common property resource conservation of community farms", Sustainability, Vol. 12 No. 12, p. 5137.

Korhonen, J., Honkasalo, A. and Seppälä, J. (2018), "Circular economy: the concept and its limitations”, Ecological Economics, Vol. 143, pp. 37-46.

Lai, K.H., Wu, S.J. and Wong, C.W.Y. (2013), "Did reverse logistics practices hit the triple bottom line of Chinese manufacturers?", International Journal of Production Economics, Vol. 146, pp. 106-117.

Li, Y. (2014), "Environmental innovation practices and performance: moderating effect of resource commitment", Journal of Cleaner Production, Vol. 66, pp. 450-458.

Liu, S., Eweje, G., He, Q. and Lin, Z. (2020), “Turning motivation into action: a strategic orientation model for green supply chain management", Business Strategy and the Environment, Vol. 29 No. 7, pp. 2908-2918.

Lopez-Becerra, E.I. and Alcon, F. (2021), "Social desirability bias in the environmental economic valuation: an inferred valuation approach", Ecological Economics, Vol. 184, p. 106988.

Mahindroo, A., Samalia, H.V. and Verma, P. (2018), "Moderated influence of return frequency and resource commitment on information systems and reverse logistics strategic performance", International Journal of Productivity and Performance Management, Vol. 67, pp. 550-570.

Maiti, M., Krakovich, V., Shams, S.M.R. and Vukovic, D.B. (2020), "Resource-based model for small innovative enterprises", Management Decision, Vol. 58 No. 8, pp. 1525-1541.

Makarova, I., Shubenkova, K., Pashkevich, A. and Shepelev, V. (2018), "The role of reverse logistics in the transition to a circular economy", International Conference on Reliability and Statistics in Transportation and Communication, pp. 363-373.

Mao, H., Liu, S., Zhang, J. and Deng, Z. (2016), "Information technology resource, knowledge management capability, and competitive advantage: the moderating role of resource commitment", International Journal of Information Management, Vol. 36 No. 6, pp. 1062-1074.

Marić, J. and Opazo-Basáez, M. (2019), "Green servitisation for flexible and sustainable supply chain operations: a review of reverse logistics services in manufacturing", Global Journal of Flexible Systems Management, Springer, Vol. 20 No. 1, pp. 65-80. 
MATREDE (2020), "Malaysia external trade development corporation: automotive components", available at: https://www.matrade.gov.my/en/malaysian-exporters/services-for-exporters/trademarket-information/trade-statistics.

McDougall, N., Wagner, B. and MacBryde, J. (2019), "An empirical explanation of the natural-resourcebased view of the firm”, Production Planning and Control, Vol. 30 No. 16, pp. 1366-1382.

Merli, R., Preziosi, M. and Acampora, A. (2018), "How do scholars approach the circular economy? A systematic literature review", Journal of Cleaner Production, Vol. 178, pp. 703-722.

Michalisin, M.D. and Stinchfield, B.T. (2010), "Climate change strategies and firm performance: an empirical investigation of the natural resource-based view of the firm", Journal of Business Strategies, Vol. 27 No. 2, pp. 123-149.

Mousa, S.K. and Othman, M. (2020), "The impact of green human resource management practices on sustainable performance in healthcare organisations: a conceptual framework", Journal of Cleaner Production, Vol. 243, p. 118595.

Ngu, H.J., Lee, M.D. and Osman, M.S.B. (2020), "Review on current challenges and future opportunities in Malaysia sustainable manufacturing: remanufacturing industries", Journal of Cleaner Production, p. 123071.

Niţă, C.G. and Ştefea, P. (2014), "Cost control for business sustainability", Procedia - Social and Behavioral Sciences, Vol. 124, pp. 307-311.

Passarini, F., Ciacci, L., Santini, A., Vassura, I. and Morselli, L. (2012), "Auto shredder residue LCA: implications of ASR composition evolution", Journal of Cleaner Production, Vol. 23 No. 1, pp. 28-36.

Pieroni, M.P., McAloone, T.C. and Pigosso, D.C. (2021), "Circular Economy business model innovation: sectorial patterns within manufacturing companies", Journal of Cleaner Production, Vol. 286, p. 124921.

Pirttilä, M., Virolainen, V.M., Lind, L. and Kärri, T. (2020), "Working capital management in the Russian automotive industry supply chain", International Journal of Production Economics, Vol. 221, p. 107474.

Prieto-Sandoval, V., Jaca, C. and Ormazabal, M. (2018), "Towards a consensus on the circular economy", Journal of Cleaner Production, Vol. 179, pp. 605-615.

Ringle, C.M. and Sarstedt, M. (2016), "Gain more insight from your PLS-SEM results the importanceperformance map analysis", Industrial Management and Data Systems, Vol. 116, pp. 1865-1886.

Rogers, D.S. and Tibben-Lembke, R.S. (1999), Going Backwards: Reverse Logistics Trends and Practices, Reverse Logistics Executive Council Publishing, Pittsburgh.

Richey, R.G. Jr, Musgrove, C.F., Gillison, S.T. and Gabler, C.B. (2014), "The effects of environmental focus and program timing on green marketing performance and the moderating role of resource commitment”, Industrial Marketing Management, Vol. 43, pp. 1246-1257.

Sanni, S., Jovanoski, Z. and Sidhu, H.S. (2020), "An economic order quantity model with reverse logistics program”, Operations Research Perspectives, Vol. 7, p. 100133.

Saraiva, M.B., Ferreira, M.D.P., da Cunha, D.A., Daniel, L.P., Homma, A.K.O. and Pires, G.F. (2020), "Forest regeneration in the Brazilian Amazon: public policies and economic conditions", Journal of Cleaner Production, Vol. 269, p. 122424.

Saxena, L.K., Jain, P.K. and Sharma, A.K. (2018), "Tactical supply chain planning for tyre remanufacturing considering carbon tax policy", International Journal of Advanced Manufacturing Technology, Vol. 97, pp. 1505-1528.

Shen, K.W., Li, L. and Wang, J.Q. (2020), "Circular economy model for recycling waste resources under government participation: a case study in industrial waste water circulation in China", Technological and Economic Development of Economy, Vol. 26, pp. 21-47.

Sinkovics, N., Hoque, S.F. and Sinkovics, R.R. (2018), "Supplier strategies and routines for capability development: implications for upgrading", Journal of International Management, Vol. 24 No. 4, pp. 348-368. 
EJMBE 32,1
Thierry, M., Solomon, M., Van Nunen, J. and Van Wassenhove, L. (1995), "Strategic issues in product recovery management”, Long Range Planning, Vol. 28, p. 120.

Tosarkani, B.M., Amin, S.H. and Zolfagharinia, H. (2020), "A scenario-based robust possibilistic model for a multi-objective electronic reverse logistics network", International Journal of Production Economics, Vol. 224 No. 107557, pp. 1-22.

US ITC (2012), Remanufactured Goods: An Overview of the U.S. and Global Industries, U.S. International Trade Commission, Washington.

Vijayaraghavan, A., Yuan, C., Diaz, N., Fleschutz, T. and Helu, M. (2013), “Closed-loop production systems", Green Manufacturing, Springer, Boston.

Zaid, A.A., Jaaron, A.A.M.M., Talib Bon, A., Bon, A.T., Talib Bon, A. and Bon, A.T. (2018), “The impact of green human resource management and green supply chain management practices on sustainable performance: an empirical study", Journal of Cleaner Production, Vol. 204, pp. 965-979.

Zhao, S., You, Z. and Zhu, Q. (2021), "Quality choice for product recovery considering a trade-in program and third-party remanufacturing competition", International Journal of Production Economics, Vol. 240, p. 108239.

Zhu, J., Fan, C., Shi, H. and Shi, L. (2019), "Efforts for a circular economy in China: a comprehensive review of policies", Journal of Industrial Ecology, Vol. 23 No. 1, pp. 110-118.

\section{Corresponding author}

Yudi Fernando can be contacted at: yudifernando.td@gmail.com

For instructions on how to order reprints of this article, please visit our website:

www.emeraldgrouppublishing.com/licensing/reprints.htm

Or contact us for further details: permissions@emeraldinsight.com 